International Journal of Current Advanced Research

ISSN: O: 2319-6475, ISSN: P: 2319 - 6505, Impact Factor: SJIF: 5.995

Available Online at www.journalijcar.org

Volume 6; Issue 3; March 2017; Page No. 2783-2785

DOI: http://dx.doi.org/10.24327/ijcar.2017.2785.0103

Review Article

\title{
LONG ACTING LOCAL ANESTHETICS IN DENTISTRY- A review
}

\author{
*M.Pooja Umaiyal and M.Dhanraj
}

Department of Prosthodontics, Saveetha Dental College, Chennai.

\section{A R T I C L E I N F O}

\section{Article History:}

Received $18^{\text {th }}$ December, 2016

Received in revised form $16^{\text {th }}$ January, 2017

Accepted $26^{\text {th }}$ February, 2017

Published online $28^{\text {th }}$ March, 2017 \begin{abstract}
A B S T R A C T
The aim of this review is to provide an adequate knowledge on long acting anaesthetics like Bupivacaine, tetracaine, etidocaine, ropivacaine and merivacaine in oral cavity along with its complications which include both local and systemic complications.Local anesthesia is defined as a loss of sensation in a circumscribed area of the body by a depression of excitation in nerve endings or an inhibition of the conduction process in the peripheral nerves. The reason for this review is to provide sufficient knowledge on long acting anaesthetics along with its complications.
\end{abstract}

Key words:

Local anesthetics, Bupivacaine, tetracaine,

etidocaine, ropivacaine,merivacaine

Copyright $\bigcirc 2017$ M.Pooja Umaiyal and M.Dhanraj. This is an open access article distributed under the Creative Commons Attribution License, which permits unrestricted use, distribution, and reproduction in any medium, provided the original work is properly cited.

\section{INTRODUCTION}

For more than 100 years, local anesthetics has been in use in dental practice.The advent of local anaesthetics with the development of nerve blockade injection techniques heralded a new era of patient comfort while permitting more extensive and invasive dental procedures.Dentistsare able to select an anaesthetic that acquirescertain definite properties such as time of onset and duration, hemostatic control, and degree of cardiac side effects that are appropriate for each individual patient and for each specific dental procedure due to advance and availability of variety of local anesthetic agents.[1]

Both intra-operative and postoperative pain has been proved to be effectively suppressed by the use of long-acting local anesthetics [2]. There are several factors that influence the choice of local anesthetics; they should meet the expectations for post-operative pain management by providing effective anesthesia and analgesia for the duration of the procedure. The local anesthetic drugs that are currently available for use in dentistry are divided into three categories. Short-acting drugs, suchas $4 \%$ prilocaine, $3 \%$ mepivacaine, and $2 \%$ lidocaine, provide $30 \mathrm{~min}$ orless of pulpalanesthesia. Few examples of intermediate duration agents (approximately 60 min of pulpalanesthesia) are two percent lidocaine with 1:100,000 epinephrine, 2\% mepivacaine with 1:20,0001 evonordefrin, 4\% prilocaine with 1:200,000 epinephrine, and $2 \%$

\footnotetext{
*Corresponding author: M.Pooja Umaiyal

Department of Prosthodontics, Saveetha Dental College, Chennai.
}

procaineplus $0.4 \%$ propoxycaine with either 1:20,0001 evonordefrinor 1:30,000 norepinephrine. Long-duration agents (up to $90 \mathrm{~min}$ or more of pulpalanesthesia) include $0.5 \%$ bupivacaine with 1: 200,000 epinephrine, and 1.5\% etidocaine with 1:200,000 epinephrine.1'2.ropivacaineis ultimately proved to be useful in the practice of dentistry as a third long-duration local anesthetic agent.[2]

\section{Lidocaine}

It is also known as xylocaine and lignocaine. It is the most widely used local anesthetic agent in dentistry is $2 \%$ lidocaine with 1:100,000 epinephrine. It is routinely used for all types of dental procedures ranging from simple amalgam restoration to complex surgical procedures due to its explicit properties such as rapid onset, low toxicity, low incidence of allergy, and its relatively low cost when compared to other anesthetic agents.Sleepiness, muscle twitching, confusion, changes in vision, numbness, tingling, and vomiting are some of its common side effects with intravenous usage. It can also cause low blood pressure and an irregular heart rate.[3] it's use in pregnancy is generally considered to be safe. Patients involved with liver problems have to be provided with lower dose of the agent.[3] It is generally safe to use in those allergic to tetracaine or benzocaine.[4]

\section{Bupivacaine}

It is a local anaesthetic of the amide group.[1]Itis indicated for local infiltration, peripheral nerve block, sympathetic nerve block, and epidural and caudal blocks. At times it is used in combination with epinephrine to prevent systemic absorption and extend the duration of action. 
Sleepiness, muscle twitching, ringing in the ears, changes in vision, low blood pressure, and an irregular heart rate are a few possible side effects of bupivacaine. It is contraindicated in patients with hypersensitive reactions to bupivacaine or amino-amide anesthetics. It differs from mepivacaine only in the substitution of a butyl group for the methyl group at the amine end of the molecule. Although the structural formula differs only slightly but chemically it differs significantly. Bupivacaine and etidoocaine have structural for mulae which differonly slightly from those of mepivacaine and lido caine, respectively, they differby some physicochemical properties. Bupivacaine and etidocaine have, forexample, a much higher degree of lipid solubility and protein-binding capacity.[5]

\section{Etidocaine}

Duranest is the trade name under which etidocaine is marketed., it is an amine type local anesthetic given by injection during surgical procedures. It is similar in structure to lidncaine but differs by an addition of a propyl groupfor an ethyl group at the amine end and an addition of an ethyl group on an alpha carbon on an intermediate chain. It is 50 time more lipid soluble than lidocaine. It's plasma protein binding is similar to that of bupivacaine $(95 \%)$ and greater than that of lidocaine $(65 \%)$ or mepivacaine $(75 \%)$. It has also been reported to produce a lower blood concentration.[2] Etidocaine has a long duration of activity, but the main disadvantage of using it during dentistry is that it increases bleeding during surgery.[6]

\section{Tetracaine}

Tetracaine is an ester-typelong-actinglocalanesthetic. It has delayedon set and significant toxi city; itisnotused by injecti on for dental loca lanesthesia. In biomedical research, tetracaine is used to alter the function of calcium release channels that control the release of calcium from intracellular stores. It is an allosteric blocker of channel function. At low concentrations, tetracaine causes an initial inhibition of spontaneous calcium release events, while at high concentrations, it blocks release completely.[7] It is mainly used topically in ophthalmology and as an antipruritic, and it has been used in spinal anesthesia.

\section{Ropivacaine}

It is also a local anaesthetic drug which belongs to the aminoamide group. [2] It's name refers to both the racemate and the marketed S-enantiomer. Ropivacaine is indicated for local anaesthesia including infiltration, nerve block, epidural and intrathecal anaesthesia in adults and children over 12 years. It is also indicated for peripheral nerve block and caudal epidural in children 1-12 years for surgical pain. It is also sometimes used for infiltration anaesthesia for surgical pain in children.

\section{Mepivacaine}

It is supplied as the hydrochloride salt of the racemate, [8] which consists of R (-)-mepivacaine and S (+)-mepivacaine in equal proportions. These two enantiomers have markedly different pharmacokinetic properties. [9] It is a local anesthetic [10] of the amide type. Mepivacaine has a reasonably rapid onset and medium duration of actionand is marketed under various trade names including Carbocaine and Polocaine.
The onset time, duration of anesthetics and analgesia of certain local anesthetics have been tabulated in table 1.1.

Table1.1 Anaesthetics and its duration of onset, analgesia and anaesthetics

\begin{tabular}{|c|c|c|c|}
\hline Anaesthetics & $\begin{array}{l}\text { Onset } \\
(\mathrm{min})\end{array}$ & $\begin{array}{c}\text { Duration of } \\
\text { anaesthetic (hr) }\end{array}$ & $\begin{array}{c}\text { Duration of } \\
\text { analgesia (hr) }\end{array}$ \\
\hline $\begin{array}{l}\text { 3\% 2-Chloroprocaine }+ \\
\text { epinephrine }\end{array}$ & $10-15$ & $1.5-2$ & $2-3$ \\
\hline $1.5 \%$ Mepivacaine & $10-20$ & $2-3$ & $3-5$ \\
\hline $\begin{array}{l}1.5 \% \text { Mepivacaine + } \\
\text { epinephrine }\end{array}$ & $10-20$ & $2-5$ & $3-8$ \\
\hline $2 \%$ Lidocaine + epinephrine & $10-20$ & $2-5$ & $3-8$ \\
\hline $0.5 \%$ Ropivacaine & $15-30$ & $4-8$ & $5-12$ \\
\hline $0.75 \%$ Ropivacaine & $10-15$ & $5-10$ & $6-24$ \\
\hline $\begin{array}{l}0.5 \% \text { Bupivacaine }+ \\
\text { epinephrine }\end{array}$ & $15-30$ & $5-15$ & $6-30$ \\
\hline
\end{tabular}

\section{Complications}

Complications include both local and systemic complications.[11] Local complications include spread of infection, hematoma, nerve damage and blockade of the facial nerve. Where as systemic complications include regional or systemic infection, endocarditis risk, Pseudocholinesterase deficiency, cardiovascular disease, liver disease and Methemoglobinemia.

\section{Local Complications}

Spread of infection: seldom infections spread into thet issues By the needle as it passes through a contaminatedtissueorbycontamination of the needle itself before it's use. Hematoma: Hematoma is formed as a result of damage of a blood vessel caused by the tip of a needle which may lead to bleeding within thetissues. Significant bleeding maycause pain, swelling and trismus. Nerve damage: at times, the needle may pierce a nerve bundle during its placement, producing an immediate electric shock sensation to the patient. It is usually followed by a partial sensory deficit, but subsequently a complete return to normal sensation usually follows. Blockade of the facial nerve: a motor blockade causing temporaryparalys is of them uscles official expression may occur if the injection is provided in close proximity to the facial nerve. The effect may last for an hour or two.

\section{Systemiccomplications}

Regional or systemic infection: passage of a needle through an infected area within the perioral tissues can be potentially spread through planes of the head and neck. Endocard it is risk: certain injections like the intraligamentary injection can force bacteria into the systemic circulation and cause bacterial endocarditis. Cardiovascular disease: patients with cardiac related problems show higher plasma levels of lidocaine when compared with that of healthy subjects given the same dose. Therefore it is recommended that the maximum safe dose be halve dinsuch patients. [12] Liver disease: an abnormally decreased rate of metabolism of amide local anaesthetics, resulting in potentially toxic blood levels is exhibited in patients with reduced hepatic functions. Dosage levels must therefore be reduced for these patients. Methemoglobinemia: this is a rare complication caused by ametabolite of prilocaine that oxidizes the ferrous component of heme in red blood cells to the ferricstate. This reduces their oxygen delivering capacity and results in tissue hypoxia. 


\section{CONCLUSION}

Longactinglocalanestheticshave a rapid onset of action, a minimal incidence of associated side effects, they delay the onset of post operative pain and also reduces the intensity of post operative pain. Hence it is effective for suppression of intra operative pain. The most signify cant depressant and dysrhythmogenic effects on the cardiovascular systemic of bupivacaine. Etidocaine may have a slightly more rapid onset of action, but its use may be associated with increased intraoperative bleeding. A new long-acting local anesthetic, ropivacaine, may be effective for prolonged anesthesia and post operative analgesia without the need for added vasoconstrictor.

\section{Reference}

1. Local Anesthetics in Dentistry: Then and Now

2. AllenL. Sisk, DDS. Long-Acting Local Anestieticsin Dentsty. AnesthProg39:53-601992

3. "Lidocaine Hydrochloride (Antiarrhythmic)". The American Society of Health-System Pharmacists. Retrieved Aug 26, 2015

4. "Lidocaine Hydrochloride (Local)". The American Society of Health-System Pharmacists. Retrieved Aug $26,2015$.
5. Covino BG and Vassallo HG: Local anesthetics. Mechanisms of Action and Clinical Use. Grune \& Stratton, NewYork, 1971.

6. Sisk, A. L. (1992). "Long-acting local anesthetics in dentistry". Anesthesia Progress. 39 (3): 53-60

7. Györke, S; Lukyanenko, V; et al. (1997). "Dual effects of tetracaine on spontaneous sodium release in rat ventricular myocytes". 500 (2). J Physiol: 297-309.

8. Burm AG, Cohen IM, van Kleef JW, Vletter AA, Olieman W, Groen K (January 1997). "Pharmacokinetics of the enantiomers of mepivacaine after intravenous administration of the racemate in volunteers". Anesth. Analg. 84 (1): 85-9.

9. http://journals.lww.com/anesthesiaanalgesia/Fulltext/1 997/01000/Pharmacokinetics_of_the_Enantiomers_of Mepivacaine.16.aspx

10. Porto GG, Vasconcelos BC, Gomes AC, Albert D (January 2007). "Evaluation of lidocaine and mepivacaine for inferior third molar surgery" (PDF). Med Oral Patol Oral Cir Bucal. 12 (1): E60-4.

11. Chen AH. Toxi city and allergy to local anesthesia. $J$ CalifDentAssoc. 1998; 26:683-692.

12. Preshaw PM, Rowson JE. The use of lignocaine local anaesthetic. Br Dent J. 1996;181:240.

\section{How to cite this article:}

M.Pooja Umaiyal and M.Dhanraj (2017) ' Long acting local anesthetics in dentistry- a review', International Journal of Current Advanced Research, 06(03), pp. 2783-2785.

DOI: http://dx.doi.org/10.24327/ijcar.2017.2785.0103 